\title{
3. Additional Notice of the occurrence of Volcanic Bombs in
} Australasia. By the Rev. W. B. Clarke, A.M., F.G.S.

\section{[Abstract.]}

THE author sent in 1855 a notice of the occurrence of Volcanic Bombs in the gold-bearing alluvium of New South Wales*; and in this communication adds Victoria and Tasmania as countries in which these obsidian-bombs have been found in the alluvial drift.

One specimen was found by Mr. Milligan, Secretary of the Royal Society of Van Diemen's Land, on the Supply Rivulet, Spring Bay, River Tamar, in Tasmania, about twenty miles from Bass's Strait; the other specimen (like a bung in shape, an inch high and $1 \frac{2}{10}$ inch thick at the upper part) was found near the River Wannon in the district of Portland Bay.

4. Notice of the occurrence of Metalliferous Ores and of Coal in Siam. By H. J. Moyle, Esq., and C. B. Hillier, Esq., H.M. Consul at Bangkok.

[Forwarded from the Foreign Office by order of Lord Clarendon.]

(Abstract.)

Mr. Moyce states that in the hilly districts extending north and south, in lat. $15^{\circ} 25^{\prime}$, near the River Chaw-Phya (Meinam) in Siam, he has discovered several apparently valuable veins of copper-ore, principally in grauwacke, and that he has applied for and obtained from the Siamese government authority to work them. He also refers to his discovery of ores of lead and silver, with enormous beds of magnetic and specular iron-ores in the same district; and describes the country to the north as consisting of carboniferous limestone, with indications of coal.

Mr. Moyle states that the numerous rivers and canals afford great facilities for the transport of the minerals from the hills; and he believes that Siam will rival any country in the East in the richness of its mineral productions.

Mr. Hillier mentions a report that beds of coal have been discovered near the sea in the district of Chantabun on the eastern coast of the Gulf of Siam.

Note.-A small box of ores, chiefly cupriferous, with a specimen of corundum, accompanied this communication from the Foreign Office; but these were not sufficient to decide the question of the value of the ores.-EDit.

* Quart. Journ. Geol. Soc. vol. xi. p. 405. 